\title{
FAKTOR - FAKTOR YANG MEMPENGARUHI RENDAHNYA KUNJUNGAN BALITA ( 1-5 TAHUN) KE POSYANDU DAMAI SEJAHTERA STIKES AL-MA'ARIF BATURAJA TAHUN 2019
}

\author{
FACTORS THAT INFLUENCE THE LOWEST VISIT TO CHILDREN (1-5 YEARS) TO \\ POSYANDU DAMAI SEJAHTERA STIKES AL-MA'ARIF BATURAJA IN 2019 \\ Rini Camelia \\ Program Studi Kebidanan Sekolah Tinggi Ilmu Kesehatan Al-Ma'arif Baturaja, Sumatera \\ Selatan \\ email: rini_camelia93@yahoo.co.id
}

\begin{abstract}
ABSTRAK
Posyandu banyak memiliki manfaat bagi masyarakat, dimana masyarakat mendapat kemudahan dalam memperoleh informasi dari pelayanan kesehatan bagi ibu, bayi, dan anak balita. Pertumbuhan bayi dan balita juga dapat terpantau sehingga tidak mengalami menderita gizi buruk,bayi dan balita mendapatkan vitamin A, bayi dapat memperoleh imunisasi yang lengkap. Dari data yang di peroleh dari posyandu Damai Sejahtera STIKES AL-MA'ARIF BATURAJA setiap bulannya memiliki penurunan yaitu, dari bulan Oktober 2018 jumlah kunjungan bayi dan balita 33 bayi dan balita,bulan November 2018 jumlah kunjungan bayi dan balita menurun menjadi 28 bayi dan balita,bulan Desember 2018 jumlah kunjungan bayi dan balita menurun menjadi 15 bayi dan balita,bulan Januari 2019 jumlah kunjungan bayi dan balita menjadi 14 bayi dan balita,bulan Febuari 2019 jumlah kunjungan bayi dan balita menjadi 17 bayi dan balita,bulan Maret 2019 jumlah kunjungan bayi dan balita menjadi 12 bayi dan balita. Partisipasi dalam penelitian ini adalah ibu yang memiliki balita ( 1-5 tahun ) di wilayah kerja UPTD Puskesmas Sukaraya yang berjumlah 33 orang.
\end{abstract}

Kata Kunci : Balita; Kunjungan Posyandu Balita; Penurunan; Posyandu; Pendidikan; Pekerjaan; Pengetahuan

\begin{abstract}
Posyandu has many benefits for the community, where people facilitated to obtain information from health care for mothers, infants, and toddlers. Growth of infants and toddlers can alsobe monitored so as not to experience suffering from malnutrition, infant and toddler get vitamin A, a baby can abtain a complete immunization. From the data obtained from the posyandu peace and prosperity Stikes Al-Ma'Arif Baturaja every month has a decrease that is, from Oktober 2018 the number of baby visits and toddlers 33 babies and toddlers, in November 2018 the number of infants and toddler visits decreased to 28 infants and toddlers, in December 2018 the number of infants and toddler visits decreased to 15 infants and toddlers, in January 2019 the number of infants and toddlers visits will be 14 infants and toddlers, in February 2019 the number of infants and toddlers visits will be 17 infants and toddlers, in March 2019 the number of infants and toddlers visits will be 12 infants and toddlers, Participants in this study werw mothers of children under five (1-5 years) in the working areaof the Sukaraya Community Health Center, which numbered 33 people.
\end{abstract}

Keywords : Toddlers; Posyandu toddlers visits; Decline; Posyandu; education; Knowledge work 
CENDEKIA MEDIKA

p-ISSN: 2503-1392

e-ISSN: 2620-5424

\section{PENDAHULUAN}

Posyandu adalah salah satu Upaya Kesehatan Bersumber Daya Masyarakat (UKBM) yang dikelola dan diselenggarakan dari, oleh, untuk dan bersama masyarakat dalam penyelenggaraan pembangunan kesehatan guna memberdayakan masyarakat dan memperoleh pelayanan kesehatan dasar untuk memperlancarkan penurunan angka kematian ibu dan bayi ${ }^{1}$.

Tujuan diselenggarakan Posyandu ialah untuk menurunkan angka kematian ibu dan anak, meningkatkan pelayanan kesehatan ibu untuk menurunkan IMR (Infant Mortality Rate)/angka kematian bayi, mempercepat penerimaan NKKBS (Norma Keluarga Kecil Bahagia Sejahtera), meningkatkan kemampuan masyarakat untuk mengembangkan kegiatan kesehatan dan untuk menunjang peningkatan hidup sehat, pendekatan dan pemerataan pelayanan kesehatan kepada masyarakat sehingga tercapai peningkatan cakupan pelayanan kesehatan, menghimpun potensi masyarakat untuk berperan serta secara aktif meningkatkan kesehatan dan kesejahteraan ibu,bayi, balita ${ }^{2}$.

Pelaksanan posyandu yaitu sebulan sekali yang ditentukan oleh kader, tim penggerak PKK desa/kelurahan serta petugas kesehatan dari Puskesmas, dilakukan pelayanan masyarakat dengan sistem lima meja. Meja I (pendaftaran), meja II(penimbangan), meja III (pengisian KMS), meja IV (penyuluhan perorangan berdasarkan KMS), meja V (pelayanankesehatan seperti imunisasi, pemberian vitamin $A$, dan pengobatan ringan). Petugas yang berada pada meja IIV adalah kader PKK sedangkan meja V merupakan meja pelayanan paramedis (juru imunisasi), bidan desa dan perawat ${ }^{3}$.

Anak balita adalah anak yang usianya antara 1-5 tahun,sedangkan usia di atasnya
Volume 6 Nomor 1, April 2021

(1-12 tahun) di sebut dengan anak usia awal sekolah.Masa balita ditandai dengan tingkat pertumbuhan yang sangat pesat sehingga pertumbuhan zat gizi yang relative lebih tinggi,sementara pemberian makanan juga akan lebih sering.Usia di bawah 5 tahun atau balita merupakan masa penting dalam pertumbuhan dan perkembangan fisik anak.Pada usia ini,anak masih rawan dengan berbagai gangguan kesehatan,baik jasmani maupun rohani. Secara psikologis, rentang usia inijuga sangat menentukan karakter anak di kemudian hari. Adapun ciri-ciri anak balita sehat: tumbuh dengan baik, terlihat aktif, gesit dan gembira, mata bersih dan bersinar, nafsu makan cukup baik, bibir dan lidah tampak segar, penapasan tidak berbau, kulit dan rambut tampak bersih dan tidak kering, dan mudah menyesuaikan diri dengan lingkungan

Balita ialah anak yang sudah memasuki usia diatas satu tahun atau lebih terkenal dengan anak usia dibawah lima tahun ${ }^{4}$.

Balita merupakan golongan yang rentan terhadap penyakit (masalah kesehatan). Gangguan kesehatan yang terjadi pada balita mempengaruhi pertumbuhan dan perkembangan baik pada masa balita maupun masa selanjutnya. Dan upaya untuk memantau pertumbuhan dan perkembangan balita salah satunya adalah dengan Posyandu ${ }^{5}$.

Ciri keberhasilan pemanfaatan pelayanan kesehatan adalah keaktifan kedatangan masyarakat ke pusat pelayanan kesehatan yang dalam hal ini khususnya pemanfaatan Posyandu. Kehadiran ibu ke Posyandu dengan membawa balitanya ke Posyandu sangatlah mendukung tercapainya salah satu tujuan Posyandu yaitu meningkatkan kesehatan ibu dan balita ${ }^{6}$.

Menurut WHO (World Health Orgazation) (2014), angka kematian bayi dan balita secara global telah menurun hampir 
CENDEKIA MEDIKA

p-ISSN: 2503-1392

e-ISSN: 2620-5424

setengah persen sejak tahun 1990.Angka kematian bayi dan balita turun dari 90 mrnjadi 46 kematian balita per 1000 kelahiran pada tahun 2013.Di Indonesia jumlah kematian anak balita telah berkurang dari 385.000 pada tahun 1990 152.000 pada tahun 2012 dengan demikian lebih dari 400 anak-anak meninggal setiap hari di Indonesia ${ }^{7}$.

Dari data yang diperoleh dari Posyandu Damai Sejahtera STIKES Al-Ma'arif Baturaja setiap bulannya memiliki penurunan yaitu, dari bulan Oktober 2018 jumlah kunjungan bayi dan balita 33 bayi dan balita,bulan November 2018 jumlah kunjungan bayi dan balita menurun menjadi 28 bayi dan balita,bulan Desember 2018 jumlah kunjungan bayi dan balita menurun menjadi 15 bayi dan balita,bulan Januari 2019 jumlah kunjungan bayi dan balita menjadi 14 bayi dan balita, bulan Febuari 2019 jumlah kunjungan bayi dan balita menjadi 17 bayi dan balita,bulan Maret 2019 jumlah kunjungan bayi dan balita menjadi 12 bayi dan balita.

\section{METODE}

Jenis penelitian yang di gunakan ini adalah survey analitik dengan pendekatan Cross Sectional yaitu suatu penelitian dimana variabel independen (pendidikan, pekerjaan, pengetahuan) dan variabel dependen (faktor-faktor rendahnya kunjungan balita (1-5 tahun) dikumpulkan dalam waktu yang bersamaan ${ }^{8}$.

Populasi dalam peneliti ini adalah seluruh ibu yang mempunyai balita usia 1-5 tahun dan yang mempunyai KMS yang berada Wilayah kerja Posyandu Damai Sejahtera STIKES Al-Ma'arif Baturaja tahun 2019 berjumlah 33 orang. Sampel adalah total populasi yang berjumlah 33 orang. Tempat penelitian dilakukan di Posyandu Damai Sejahtera STIKES Al-Ma'arif Baturaja tahun 2019. Analisa dilakukan untuk melihat hubungan variabel yang di teliti yaitu variabel independen (pendidikan, pekerjaan, pengetahuan ibu tentang posyandu) dengan variabel dependent (kunjungan posyandu balita (1-5 tahun) menggunakan uji statistic Chi-Square dengan batas kemaknaan a $=0,05$ dan derajat kepercayaan $95 \%$. Dikatakan ada hubungan yang bermakna bila value $\leq 0,05$ dan $p$ value $>0,05$ maka kedua varibel tersebut dikatakan tidak ada hubungan bermakna.

\section{HASIL}

Analisis Univariat

Analisa yang dilakukan untuk mengetahui distribusi frekuensi dan presentasi dari variabel dependen (kunjungan posyandu balita (1-5 tahun) Serta variabel independen (pendidikan, pekerjaan, pengetahuan).

Kunjungan Posyandu Balita

Tabel 1 Distribusi Frekuensi Responden Kunjungan Posyandu Balita ( 1-5 tahun )

\begin{tabular}{clcc}
\hline No & Kunjungan Posyandu Balita & Frekuensi & $\mathbf{\%}$ \\
\hline 1 & Sering & 8 & $24,2 \%$ \\
\hline 2 & Kadang-Kadang & 25 & $75,8 \%$ \\
\hline & Jumlah & $\mathbf{3 3}$ & $\mathbf{1 0 0 \%}$ \\
\hline
\end{tabular}

Data tabel 1 diketahui bahwa jumlah responden yang sering melakukan kunjungan posyandu balita sebanyak 8 responden $(24,2 \%)$ dan responden yang 
CENDEKIA MEDIKA

p-ISSN: 2503-1392

e-ISSN: 2620-5424

kadang-kadang melakukan kunjungan

posyandu balita sebanyak 25 responden

Pendidikan

Tabel 2 Distribusi Frekuensi Pendidikan Responden

\begin{tabular}{clcc}
\hline No & Pendidikan & Frekuensi & \% \\
\hline 1 & Tinggi & 28 & $84,8 \%$ \\
\hline 2 & Rendah & 5 & $15,2 \%$ \\
\hline & Jumlah & $\mathbf{3 3}$ & $\mathbf{1 0 0 \%}$ \\
\hline
\end{tabular}

Data tabel 2 diketahui bahwa jumlah responden yang pendidikannya tinggi sebanyak 28 responden $(84,8 \%)$ dan

responden yang pendidikannya rendah sebanyak 5 responden $(15,2 \%)$.
Volume 6 Nomor 1, April 2021

$(75,8 \%)$

Pekerjaan

Tabel 3 Distribusi Frekuensi Pekerjaan Responden

\begin{tabular}{clcc}
\hline No & Pekerjaan & Frekuensi & \% \\
\hline 1 & Bekerja & 15 & $45,5 \%$ \\
\hline 2 & Tidak Bekerja & 18 & $54,5 \%$ \\
\hline & Jumlah & $\mathbf{3 3}$ & $\mathbf{1 0 0 \%}$ \\
\hline
\end{tabular}

Data tabel 3 diketahui bahwa jumlah responden yang bekerja sebanyak 15 responden $(45,5 \%)$ dan responden yang 
CENDEKIA MEDIKA

p-ISSN: 2503-1392

e-ISSN: 2620-5424

tahun). Uji statistic yang dilakukan adalah uji chi-square dengan batasan kemaknaan $p$ value $\leq 0,05$ artinya ada hubungan yang bermakna (signifikan) dan bila $p$ value $>0,05$ maka tidak ada hubungan yang bermakna.

Hubungan Pendidikan Responden dengan Kunjungan Posyandu Balita di Posyandu Damai Sejahtera Wilayah Kerja Puskesmas Sukaraya STIKES Al-Ma'arif Baturaja Tahun 2019

Tabel 5 Hubungan Pendidikan Responden Dengan Kunjungan Posyandu Balita

\begin{tabular}{|c|c|c|c|c|c|c|c|c|}
\hline \multirow{3}{*}{ No } & \multirow{3}{*}{ Pendidikan } & \multicolumn{4}{|c|}{ Kunjungan Posyandu Balita } & \multirow{3}{*}{ Jumlah } & \multirow{3}{*}{$\%$} & \multirow{3}{*}{ Pvalue } \\
\hline & & \multicolumn{2}{|c|}{ Sering } & \multicolumn{2}{|c|}{ Kadang-kadang } & & & \\
\hline & & $\mathbf{F}$ & $\%$ & $\mathbf{F}$ & $\%$ & & & \\
\hline 1 & Tinggi & 6 & 21,4 & 22 & 78,6 & 28 & 100 & \\
\hline \multirow[t]{2}{*}{2} & Rendah & 2 & 40,0 & 3 & 60,0 & 5 & 100 & $0,5 / 4$ \\
\hline & Jumlah & 8 & 24,2 & 25 & 75,8 & 33 & 100 & \\
\hline
\end{tabular}

Berdasarkan tabel 5 diketahui proporsi responden pendidikan tinggi yang sering melakukan kunjungan posyandu balita sebanyak 6 responden $(21,4 \%)$ dan proporsi responden yang kadang-kadang melakukan kunjungan posyandu balita sebanyak 22 responden $(78,6 \%)$, sedangkan proporsi responden pendidikan rendah yang sering melakukan kunjungan posyandu sebanyak 2 responden (40\%) sedangkan proporsi responden yang kadang-kadang melakkukan kunjungan posyandu balita sebanyak 3 responden $(60 \%)$.

Hasil uji statistik Chi-Square diketahui $p$ value 0,574 ( $p$ value $\leq 0,05$ ). Hal ini menunjukkan tidak ada hubungan yang bermakna antara pendidikan dengan kunjungan posyandu balita.

Hubungan Pekerjaan Responden dengan Kunjungan Posyandu Balita di Posyandu Damai Sejahtera Wilayah Kerja Puskesmas Sukaraya STIKES Al-Ma'arif Baturaja Tahun 2019

Tabel 6 Hubungan Pekerjaan Responden Dengan Kunjungan Posyandu Balita

\begin{tabular}{|c|c|c|c|c|c|c|c|c|}
\hline \multirow{3}{*}{ No } & \multirow{3}{*}{ Pekerjaan } & \multicolumn{4}{|c|}{ Kunjungan Posyandu Balita } & \multirow{3}{*}{ Jumlah } & \multirow{3}{*}{$\%$} & \multirow{3}{*}{ Pvalue } \\
\hline & & \multicolumn{2}{|c|}{ Sering } & \multicolumn{2}{|c|}{ Kadang-kadang } & & & \\
\hline & & $\mathbf{F}$ & $\%$ & $\mathbf{F}$ & $\%$ & & & \\
\hline 1 & Bekerja & 5 & 33,3 & 10 & 66,7 & 15 & 100 & \multirow{2}{*}{0,418} \\
\hline 2 & Tidak Bekerja & 3 & 16,7 & 15 & 83,3 & 18 & 100 & \\
\hline & Jumlah & 8 & 24,2 & 25 & 75,8 & & 100 & \\
\hline
\end{tabular}

Berdasarkan tabel 6 diketahui proporsi responden bekerja yang sering melakukan kunjungan posyandu balita sebanyak 5 responden $(33,3 \%)$ dan proporsi responden yang kadang-kadang melakukan kunjungan posyandu balita sebanyak 10 responden $(66,7 \%)$, sedangkan proporsi responden tidak bekerja yang sering melakukan kunjungan posyandu sebanyak 3 responden $(16,7 \%)$ sedangkan proporsi responden yang kadang-kadang 
CENDEKIA MEDIKA

p-ISSN: 2503-1392

e-ISSN: 2620-5424

melakkukan kunjungan posyandu balita sebanyak 15 responden $(83,3 \%)$.

Hasil uji statistik Chi-Square diketahui $p$ value 0,418 ( $p$ value > 0,05 ). Hal ini
Volume 6 Nomor 1, April 2021

menunjukkan tidak ada hubungan yang bermakna antara pekerjaan dengan kunjungan posyandu balita.

Hubungan Pengetahuan Responden dengan Kunjungan Posyandu Balita di Posyandu Damai Sejahtera Wilayah Kerja Puskesmas Sukaraya STIKES Al-Ma'arif Baturaja Tahun 2019

Tabel 7 Hubungan Pengetaguan Responden Dengan Kunjungan Posyandu Balita

\begin{tabular}{|c|c|c|c|c|c|c|c|c|}
\hline \multirow{3}{*}{ No } & \multirow{3}{*}{ Pengetahuan } & \multicolumn{4}{|c|}{ Kunjungan Posyandu Balita } & \multirow{3}{*}{ Jumlah } & \multirow{3}{*}{$\%$} & \multirow{3}{*}{ Pvalue } \\
\hline & & \multicolumn{2}{|c|}{ Sering } & \multicolumn{2}{|c|}{ Kadang-kadang } & & & \\
\hline & & $\mathbf{F}$ & $\%$ & $\mathbf{F}$ & $\%$ & & & \\
\hline 1 & Baik & 2 & 16,7 & 10 & 83,3 & 12 & 100 & \\
\hline 2 & Sedang & 3 & 27,3 & 8 & 72,7 & 11 & 100 & 0,737 \\
\hline \multirow[t]{2}{*}{3} & Kurang & 3 & 30,0 & 7 & 70,0 & 10 & 100 & \\
\hline & Jumlah & 8 & 24,2 & 25 & 75,8 & 33 & 100 & \\
\hline
\end{tabular}

Berdasarkan tabel 7 diketahui proporsi responden pengetahuan baik yang sering melakukan kunjungan posyandu balita sebanyak 2 responden $(16,7 \%)$ dan proporsi responden yang kadang-kadang menlakukan kunjungan posyandu balita sebanyak 10 responden $(83,3 \%)$, sedangkan proporsi responden pengetahuan sedang yang sering melakukan kunjungan posyandu sebanyak 3 responden $(27,3 \%)$ dan proporsi responden yang kadang-kadang melakkukan kunjungan posyandu balita sebanyak 8 responden $(72,7 \%)$ dan proporsi responden pengetahuan kurang yang sering melakukan kunjungan posyandu balita sebanyak 3 responden ( $30 \%$ ) dan yang kadang-kadang melakukan kunjungan posyandu balita sebanyak 7 responden $(70 \%)$.

Hasil uji statistik Chi-Square diketahui $p$ value 0,737 ( $p$ value > 0,05). Hal ini menunjukkan tidak ada hubungan yang bermakna antara pengetahuan dengan kunjungan posyandu balita.

\section{PEMBAHASAN}

Hubungan Pendidikan dengan Kunjungan Posyandu Balita (1-5 tahun)

Dari hasil penelitian diketahui responden pendidikan tinggi yang sering melakukan kunjungan posyandu balita sebanyak 6 responden $(21,4 \%)$ dan proporsi responden yang kadang-kadang melakukan kunjungan posyandu balita sebanyak 22 responden $(78,6 \%)$, sedangkan proporsi responden pendidikan rendah yang sering melakukan kunjungan posyandu sebanyak 2 responden $(40 \%)$ sedangkan proporsi responden yang kadang-kadang melakkukan kunjungan posyandu balita sebanyak 3 responden (60\%).

Hasil uji statistik Chi-Square diketahui $p$ value 0,574 ( $p$ value $\leq 0,05$ ). Hal ini menunjukkan tidak ada hubungan yang bermakna antara pendidikan dengan kunjungan posyandu balita.

Hasil penelitian ini sejalan dengan penelitian Khotimah, Nyimas Nur (2009) yang menemukan tidak terdapat hubungan antara tingkat pendidikan ibu balita dengan tingkat kunjungan ibu balita ke posyandu 


\section{CENDEKIA MEDIKA}

p-ISSN: 2503-1392

e-ISSN: 2620-5424

di wilayah kerja Puskesmas Kertapati Palembang dengan nilai $p=0,32>\mathrm{a}(0,05)^{9}$.

Dari penelitian ini ibu dengan pendidikan tinggi dan kadang-kadang kunjungan posyandu proporsinya > baik. tidak ada pengaruh antara pendidikan ibu dengan kunjungan posyandu di bandingkan dengan pendidikan rendah.Di karenakan memiliki pekerjaan di luar rumah sehingga tidak sempat membawa balitanya ke posyandu dan yang menjadi alasan pula bahwa jarak tempat kerja dengan rumah dan tempat posyandu menjadi jarak atau tempat yang terdekat sehingga balitanya tidak di bawa ke posyandu Damai Sejahtera Al- Ma' Arif Baturaja.

Hubungan Pekerjaan dengan Kunjungan Posyandu Balita (1-5 tahun)

Dari hasil penelitian di ketahui responden beah kerja yang sering melakukan kunjungan posyandu balita sebanyak 5 responden $(33,3 \%)$ dan proporsi responden yang kadang-kadang melakukan kunjungan posyandu balita sebanyak 10 responden $(66,7 \%)$, sedangkan proporsi responden tidak bekerja yang sering melakukan kunjungan posyandu sebanyak 3 responden $(16,7 \%)$ sedangkan proporsi responden yang kadang-kadang melakkukan kunjungan posyandu balita sebanyak 15 responden $(83,3 \%)$.

Hasil uji statistik Chi-Square diketahui $p$ value 0,418 ( $p$ value $\leq 0,05$ ). Hal ini menunjukkan tidak ada hubungan yang bermakna antara pekerjaan dengan kunjungan posyandu balita.

Hal ini tidak sesuai dengan hasil penelitian yang dilakukan oleh Rinawati (2014) bahwa ada Hubungan Antara Status Pekerjaan Ibu dengan Kunjungan Balita Ke Posyandu di Wilayah Kerja Puskesmas Kota Sabang tahun 2014 dengan $p$ volue $=$ $0,000^{10}$.
Dari penelitian ini porposi ibu yang tidak bekerja dan kadang-kadang membawa balitanya ke posyandu lebih $>$ di bandingkan dengan ibu yang bekerja di karenakan ibu yang tidak bekerja dengan tingkat sosial ekonomi yang tingkat lebih sering membawa balitanya ke dokter atau ke rumah sakit dari pada ke posyandu.

Hubungan Pengetahuan dengan Kunjungan Posyandu Balita (1-5 tahun)

Dari hasil pengetahuan di ketahui responden pengetahuan baik yang sering melakukan kunjungan posyandu balita sebanyak 2 responden $(16,7 \%)$ dan proporsi responden yang kadang-kadang melakukan kunjungan posyandu balita sebanyak 10 responden $(83,3 \%)$, sedangkan proporsi responden pengetahuan sedang yang sering melakukan kunjungan posyandu sebanyak 3 responden $(27,3 \%)$ dan proporsi responden yang kadang-kadang melakkukan kunjungan posyandu balita sebanyak 8 responden $(72,7 \%)$ dan proporsi responden pengetahuan kurang yang sering melakukan kunjungan posyandu balita sebanyak 3 responden ( $30 \%$ ) dan yang kadang-kadang melakukan kunjungan posyandu balita sebanyak 7 responden $(70 \%)$.

Hasil uji statistik Chi-Square diketahui $p$ value 0,737 ( $p$ value $\leq 0,05$ ). Hal ini menunjukkan tidak ada hubungan yang bermakna antara pengetahuan dengan kunjungan posyandu balita.

Hal ini tidak sesuai dengan hasil penelitian yang di lakukan oleh Hasan, Nur Ain Oliviana (2013) bahwa ada hubungan antara tingkat pengetahuan ibu dengan partisipasi ibu balita dalam kegiatan posyandu di Kelurahan Kayumerah Kecamatan Limboto Kabupaten Gorontalo dengan $p$ value $=0,000^{11}$. 
CENDEKIA MEDIKA

p-ISSN: 2503-1392

e-ISSN: 2620-5424

Pada penelitian ini terdapat bahwa tidak ada hubungan antara pengetahuan ibu dengan kunjungan posyandu balita karena ibu yang berpengetahuan baik justru lebih sering membawa balitanya untuk menimbang dan mengukur tinggi badan balitanya sendiri dan bila balita sakit terkadang ibu datang ke klinik dokter atau rumah sakit.

\section{KESIMPULAN}

Berdasarkan penelitian di Posyandu Damai Sejahtera STIKES Al- Ma'arif Baturaja Tahun 2019 dapat ditarik kesimpulan sebagai berikut :

1. Tidak ada hubungan yang bermakna pendidikan dengan kunjungan posyandu balita ( 1-5 tahun ).Dengan hasil analisa Bivariat hasil uji statistic Chi-square di proleh nilai $p$ volue 0,574 .

2. Tidak ada hubungan yang bermakna pekerjaan dengan kunjungan posyandu balita ( 1-5 tahun ).Dengan hasil analisa Bivariat hasil uji statistic Chi-square di proleh nilai $p$ value 0,418 .

3. Tidak ada hubungan yang bermakna pengetahuan dengan kunjungan posyandu balita ( 1-5 tahun ).Dengan hasil analisa Bivariat hasil uji statistic Chi-square di proleh nilai $p$ value 0,737 .

\section{SARAN}

Hasil penelitian di harapkan dapat memberikan informasi dan masukan yang bermanfaat bagi Posyandu Damai Sejahtera STIKES Al-Ma'arif Baturaja untuk lebih meningkatkan pelayanan penyuluhan kesehatan terhadap ibu dan balitanya. Al-Insan Baturaja dan sebagai bahan referensi kepustakaan. Di harapkan peran serta masyarakat untuk selalu memberikan dukungan kepada keluarganya jika ada di dalam keluarganya terdapat balita yang tidak di bawa ibunya ke posyandu.

\section{DAFTAR PUSTAKA}

1. Kementerian Kesehatan Republik Indonesia. 2016. Profil Kesehatan Indonesia Tahun 2016. Katalog Dalam Terbitan. Kementerian Kesehatan RI. Jakarta.

2. Cahyo, dkk, 2010. Sistem Kesehatan. Jakarta : Rajawali Pers.

3. Mubarak, 2009. Ilmu Kesehatan Masyarakat Konsep dan Aplikasi dalam Kebidanan .Jakarta : Salemba Medika .

4. Muaris, H. 2006. Lauk Bergizi Untuk Anak Balita. Jakarta: Gramedia Pustaka Utama.

5. Supariasa, IDN., Bachyar, B., dan Ibnu F.2002. Penilaian Status Gizi. Jakarta:EGC.

6. Adisasmito, W. 2007.Sistem Kesehatan.Jakarta: PT. Raja Grafindo Persada.

7. World Health Organization, 2016. Monitoring Health Fot The SDGs, Sustainable Development Goals

8. Notoatmodjo,S.2012.Promosi

Kesehatan dan Perilaku Kesehatan. Jakarta: Rineka Cipta

9. Khotimah, Nyimas Nur. 2009. FaktorFaktor yang Berhubungan dengan Tingkat Kunjungan Balita ke Posyandu di Wilayah Kerja Puskesmas Kertapati Palembang. Ilmiah Volume 1 No. 3 Politeknik Kesehatan Palembang

10. Rinawati, 2014. Faktor-Faktor Yang Berhubungan Dengan Rendahnya Kunjungan Balita Ke Posyandu Di Wilayah Kerja Puskesmas Sukakarya Kota Sabang.Skripsi. Sekolah Tinggi Ilmu Kesehatan U'budiyah ProgramStudi Diploma IV Kebidanan, Banda Aceh.

11. Hasan Nur Ain Oliviana . 2013. Faktor-Faktor Yang Berhubungan Dengan Partisipasi Ibu Balita dalam Kegiatan Posyandu di Kelurahan Kayumerah Kecamatan Limboto Kabupaten Gorontalo. Skripsi. 
CENDEKIA MEDIKA

p-ISSN: 2503-1392

e-ISSN: 2620-5424

Fakultas Ilmu-Ilmu Kesehatan dan Keolahragaan Universitas Negeri

Gorontalo Tahun 